Research, Society and Development, v. 9, n. 10, e3619108629, 2020

(CC BY 4.0) | ISSN 2525-3409 | DOI: http://dx.doi.org/10.33448/rsd-v9i10.8629

\title{
Use of applications for leaching Learning Chemistry
}

Uso de aplicativos para o ensino Aprendizagem de Química

Uso de aplicaciones para la enseñanza del Aprendizaje de Química

Received: 09/20/2020 | Reviewed: 09/24/2020 | Accept: 09/28/2020 | Published: 09/30/2020

Maria Idaiane Bezerra Cavalcante

ORCID: https://orcid.org/0000-0002-1796-5170

Universidade Federal do Ceará, Brasil

E-mail: idaianebezerra13@hotmail.com

Jakson Fernandes Lima

ORCID: https://orcid.org/0000-0001-9759-3188

Universidade Federal do Ceará, Brasil

E-mail: jaksonfernandeslima@gmail.com

Railo Cavalcante Nunes

ORCID: https://orcid.org/0000-0003-2297-4036

Universidade Federal do Ceará, Brasil

E-mail: raylocavalcante@hotmail.com

Daniel Alves da Silva

ORCID: https://orcid.org/0000-0003-3650-4828

Universidade Estadual do Ceará, Brasil

E-mail: danielsilvaquimico@gmail.com

Glória Fernandes Lima

ORCID: https://orcid.org/0000-0003-0087-0578

Universidade Estadual do Ceará, Brasil

E-mail: gloriafernandeslima@gmail.com

Rubya Macêdo Lima

ORCID: https://orcid.org/0000-0003-1368-3499

Universidade Estadual do Ceará, Brasil

E-mail: rubyaml@hotmail.com.br

Rosilene Rosa Rodrigues

ORCID: https://orcid.org/0000-0002-0810-0538

Universidade Estadual Vale do Acaraú, Brasil

E-mail: rosilenerosa2013@gmail.com 
Maria Izabel Florindo Guedes ORCID: https://orcid.org/0000-0002-4569-8663

Universidade Estadual do Ceará, Brasil E-mail: florinfg@uol.com.br

\title{
Luiz Francisco Wemmenson Gonçalves Moura
}

ORCID: https://orcid.org/0000-0001-5854-6709

Universidade Estadual do Ceará, Brasil

E-mail: wemmenson.moura@uece.br

\begin{abstract}
Technology and education have always had a loving relationship, especially in the classroom. For Education in Chemistry, smartphones and their Apps can provide experiences that were previously restricted to a laboratory experiment. The purpose of this study was to investigate through an evaluation the use of the Periodic Table Quiz applications and the Educalabs Periodic Table in the classroom, how these technologies can be integrated into teaching and what are their effects on student learning. It was held at the Municipal School of Primary Education II Roberto Antunes de Freitas in the city of Quiterianópolis-CE, in 02 classes of the 9th grade, comprising 32 students, with a methodology based on a descriptive study, empirical basis and qualitative nature. The results showed the contribution and potential that the applications offer in the learning of chemical concepts. After using these, it can be noticed that there were more correct answers in 08 of the 10 questions proposed, and $100 \%$ of the students stated that their interest in the subject increased, so they could verify the validity of exploring chemistry contents through these applications since they offer more interactive content that engages the student's genuine interest in participating in the process.
\end{abstract}

Keywords: Mobile technologies; Teaching chemistry; Use of applications.

\section{Resumo}

Tecnologia e educação sempre tiveram uma relação amorosa, sobretudo, se tratando de sala de aula. Para a Educação em Química, smartphones e seus Apps, podem proporcionar experiências que antes eram restritas a um experimento de laboratório. O presente trabalho teve como objetivo investigar através de uma avaliação, o uso dos aplicativos Tabela periódica Quiz e o Tabela Periódica Educalabs em sala de aula, como essas tecnologias pode se integrar ao ensino e quais são os seus efeitos sobre a aprendizagem dos alunos. Foi 
realizado na Escola Municipal de Ensino Fundamental II Roberto Antunes de Freitas na cidade de Quiterianópolis-CE, em 02 turmas do $9^{\circ}$ ano, compreendendo 32 alunos, com metodologia baseada em um estudo descritivo, base empírica e natureza quanto-qualitativa. Os resultados mostraram a contribuição e o potencial que os aplicativos oferecem na aprendizagem de conceitos químicos. Após a utilização destes, pode-se perceber que houve mais acertos em 08 das 10 questões propostas e 100\% dos alunos afirmaram que o seu interesse pela disciplina aumentou, podendo assim, constatar a validade de explorar conteúdos de química através desses aplicativos já que eles oferecem conteúdos mais interativos e que despertam o interesse genuíno do aluno em participar do processo.

Palavras-chave: Tecnologias móveis; Ensino de química; Uso de aplicativos.

\section{Resumen}

La tecnología y la educación siempre han tenido una relación amorosa, especialmente cuando se trata del aula. Para la educación química, los teléfonos inteligentes y sus aplicaciones pueden proporcionar experimentos que antes estaban restringidos a un experimento de laboratorio. Este estudio tuvo como objetivo investigar, a través de una evaluación, el uso de las aplicaciones de la Tabla Periódica y la Tabla Periódica Educalabs en el aula, cómo estas tecnologías pueden integrarse en la enseñanza y cuáles son sus efectos en el aprendizaje de los estudiantes. Se llevó a cabo en la Escuela Municipal de Educación Primaria II Roberto Antunes de Freitas de la ciudad de Quiterianópolis-CE, en 02 clases del $9^{\circ}$ año, conformado por 32 alumnos, con metodología basada en un estudio descriptivo, de base empírica y de carácter cualitativo. Los resultados mostraron la contribución y el potencial que ofrecen las aplicaciones en el aprendizaje de conceptos químicos. Luego de utilizar estos, se puede observar que hubo más aciertos en 08 de las 10 preguntas propuestas y el $100 \%$ de los estudiantes manifestó que aumentó su interés por la disciplina, pudiendo así verificar la validez de explorar contenidos de química a través de estas aplicaciones ya que ofrecer contenidos más interactivos que despierten el interés genuino del alumno por participar en el proceso.

Palabras clave: Tecnologías móviles; Enseñanza de la química; Uso de aplicaciones.

\section{Introduction}

Chemistry teaching, with its extensive curriculum for basic education, passes the illusion of absolute and immutable knowledge of it, which makes it inadequate in its form, as 
it ends up being out of context, since contextualization and use of technologies in the teaching of chemistry have the function of improving the learning of scientific concepts, contributing to the intellectual development of students (Santos et al., 2020). Thus, many teachers currently face significant difficulties when demystifying the traditional view of chemistry to make the subject more pleasant for students (Pinheiro et al., 2016).

Often the teaching of chemistry takes place superficially, and with an increasingly dynamic society, it was necessary to search and improve the innovated individual, with to face a society in technological, social and cultural evolution (Camillo \& Medeiros, 2018).

In this sense, the use of technologies presents itself as a pedagogical tool that can help schoolwork of discipline chemistry, since it facilitates and streamlines learning through the use of means of communication and interaction, with a favored didactic approach, it can benefit, as as well as experimental activities, the search for knowledge and the development of students via digital insertion, in a constructivist perspective in a way dynamic, autonomous and pleasant (Bedin et al., 2016).

Nichele \& Schelemmer (2014) state that digital technologies, especially mobile and wireless technologies, present new perspectives in the educational field and, through the use of applications on smartphones has been transforming the way of teaching and learning and expanding the possibilities of action and interaction between subjects, subjects and environment (including the devices and environments in which they are found), as well as the processes of collaboration and cooperation.

According to the Guidelines for Mobile Learning Policies (UNESCO 2013), mobile technologies are currently within reach of people, even where schools, books and computers are scarce. Therefore, these mobile devices can be powerful tools to contribute to education, even for students who did not have access to quality education due to geographic, economic and social issues (Gresczyscnyn et al., 2016).

The use of mobile devices makes it possible to access different environments and educational methods, making it possible to develop activities through learning with mobility (Brasil et al., 2018). In this perspective, education and information assume a significant role in this process and Chemistry, a vital science in improving the quality of life of human beings. Therefore, the potential of the smartphone device is highlighted as a new technology capable of causing innovations in education, through applications, highlighting interactivity and mobility (Gresczyscnyn et al., 2016).

Nichele \& Schelemmer (2014) indicate several applications that can be used in teaching the periodic table, among them, the Educalabs Periodic Table application that 
facilitates the understanding of the behavior of the periodic properties of elements through interactive 3D visualization. It also allows the three-dimensional observation of the atomic model of each element and its respective electronic distribution. It also mentions the Periodic Table Quiz, which presents exercises in the form of a game. Thus, this work investigates through an assessment of the use of these applications in the classroom, as these technologies can be integrated into teaching and their effects on student learning.

\section{Methodology}

This study investigated the importance of using the Periodic Table Educalabs and the Periodic Table Quiz applications in the teaching of chemistry, with a methodology based on a descriptive study, empirical basis and qualitative nature.

It was held at the Municipal School of Elementary Education II Roberto Antunes de Freitas in 02 classes of the 9th grade, afternoon shift, comprising 32 students who have more learning difficulties according to their grades. The data survey was carried out in the second half of 2018, utilizing study and application of an investigative questionnaire with closed questions about the learning of the periodic table and the use of applications in the Chemistry classes, in one of the classes, without using the application and the other after using it.

Initially, a meeting was held with the school's director, coordinators and chemistry teachers to present the research objective. Then, a research/exploratory for the construction of the observation instruments and questionnaire. A class was held on the Periodic Table in both $\mathrm{C}$ and D classes. Therefore, data were collected using observation and questionnaire scripts. After the class, the questionnaire containing 10 questions about the Periodic Table was then applied in class D (Table 1). While in class C, two applications were first used: Periodic Table Educalabs and Periodic Table Quiz and then the questionnaire was applied. There were the categorization and analysis of data collected through the construction of graphs and an interpretative approach to student communication, evaluating the general scope of the proposed objectives. 
Table 1 - Questionnaire model applied.

\section{Assessment questionnaire on the periodic table}

01) Of the alternatives below, which has only ametals?

A) $\mathrm{He}, \mathrm{Os}, \mathrm{O}, \mathrm{B}, \mathrm{H}$

B) $\mathrm{He}, \mathrm{Ne}, \mathrm{Ar}, \mathrm{Kr}, \mathrm{Xe}$

C) B, Si, As, Sb, Te

D) C, N, P, Br, I, At

02) The alkaline metal with the highest atomic number and the halogen with the lowest atomic number are, respectively:
A) Fr and F
B) $\mathrm{H}$ and At
C) $\mathrm{Li}$ and At
D) $\mathrm{Li}$ and $\mathrm{F}$

02) The alkaline metal with the highest atomic number and the halogen with the lowest atomic number are, respectively:
A) Fr and F
B) $\mathrm{H}$ and At
C) Li and At
D) $\mathrm{Li}$ and $\mathrm{F}$

03) (Ufam-AM) In the periodic classification, the elements Ba (group 2), Se (group 16) and Cl (group

17) are known, respectively, as:

A) alkali, halogen and chalcogen

B) alkaline earth, halogen and chalcogen

C) alkaline earth, chalcogen and halogen

D) alkali, halogen and noble gas

04) Which chemical element listed below has properties similar to those of oxygen $(\mathrm{O})$ :
A) Nitrogen $(\mathrm{N})$
B) Hydrogen $(\mathrm{H})$
C) Fluorine $(\mathrm{F})$
D) Sulfur (S)
05) Examples of noble gases:
A) Helium, Neon, Xenon, Germanium, Radon.
B) Krypton, Neon, Radon, Titanium, Helium.
C) Argon, Helium, Neon, Scandium, Radon.
D) Radon, Krypton, Argon, Neon, Xenon

06) The color show that is seen when fireworks are detonated is due to the presence of chemical elements added to gunpowder. For example, the color yellow is due to sodium; the red, strontium and calcium; blue, copper; green, barium; and violet, potassium.

Regarding the chemical elements mentioned in the text, it is correct to state:

A) Sodium and calcium are alkali metals.

B) Strontium and barium are alkaline earth metals.

C) Potassium and barium are alkaline earth metals.

D) Calcium is an alkali metal, and copper is a transition metal.

07) In the periodic table the elements are ordered in ascending order of:
A) Mass number.
B) Atomic mass.
C) Atomic number.
D) Atomic radius.

08) The periodic table has:

A) 7 families and 18 periods.

B) 5 periods and 15 families.

C) 5 families and 15 periods.

D) 18 families and 7 periods

09) The atomic number of the element found in the 3rd period, family $3 \mathrm{~A}$ is:

A) 10. B) 12. C) 23. D) 13.

10) 2) (UFPA) - An atom, whose atomic number is 18 , is classified in the Periodic Table as:
A) alkali metal
B) alkaline earth metal
C) earth metal 
D) Noble gas

Source: Authors.

\section{Results and Discussion}

Segundo According to a survey conducted by Nichele \& Schlemmer (2014), few studies discuss the use of tablets, smartphones, and mobile learning in Chemistry's teaching and learning process. Despite this, in a survey made by the authors, it is observed that in 2004 there were already about 760 applications in the field of education in Chemistry. Of this total, 356 applications are free apps, which is considered positive since the teacher can improve his classes from the insertion of such applications in Chemistry classes.

Therefore, there is a need to deepen the knowledge on the exposed to better understand, through research, the role of these technologies in the school environment. In this context, this work was developed in a municipal school with the objective of investigating, through an evaluation, the use of the Periodic Table Quiz and the Periodic Table Educalabs applications in the classroom, how these technologies can be integrated into teaching and what are its effects on student learning.

In classes $\mathrm{C}$ and $\mathrm{D}$, with 32 students, the questionnaire was applied to the periodic table that contained questions involving symbol, name, family, period and an atomic number of the chemical elements. In class $\mathrm{D}$, who answered the questionnaire without having previously used the Periodic Table Quiz and the Periodic Table Educalabs applications, it was possible to notice that students had many difficulties in some of the questions, especially when it came to identifying the families of some elements as shown in Graph 1. 
Graph 1 - Number of correct answers in the questionnaire without using the applications.

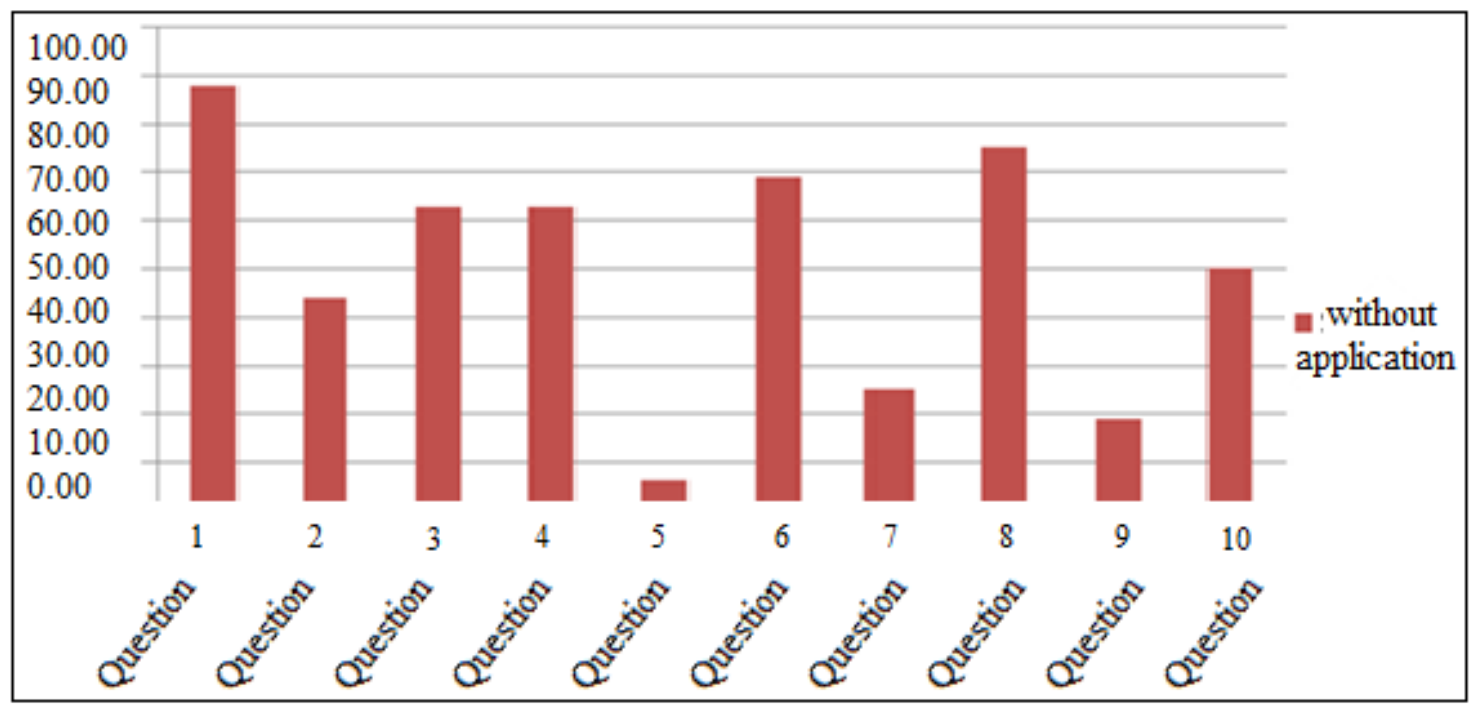

Source: Authors.

For example, in question 05, which asked about which chemical element had properties similar to those of Oxygen, only one student (6.25\%) answered correctly, which shows the lack of understanding of the periodic table as to its periodicity. In question 09, on identifying families and periods, only three students (18.75\%) answered correctly, demonstrating a lack of basic knowledge about the subject and half of the questions obtained $50 \%$ or less correct answers.

According to Bueno et al. (2008), in the discipline of chemistry, if there is no articulation between practice and theory, the contents will not be relevant to the formation of the individual or will have little contribution to his cognitive development. However, it seems that chemistry teaching has not offered conditions for the student to understand concepts, nor its relationship with everyday life.

In schools' reality, what is perceived are complaints and dissatisfaction from students regarding the monotonous and repetitive methodology adopted by teachers. Currently, technological resources considered attractive and familiar to students could be explored, aiming at more pleasurable and meaningful learning, appropriate to reality, making the student an active participant in a world in constant transformation (Silva, 2015).

Due to this reality, there is a need for innovation in teaching, considering the social segments and school planning, which points out new directions for a new way of teaching chemistry. This way involves new technologies, which have been advancing rapidly, and they are so present in the students' daily lives (Gresczysczyn, 2016). 
For Kenski (2004, p.92):

A new time, a new space and other ways of thinking and doing education are required in the information society. The wide access and wide use of new technologies condition the reorganization of curricula, management methods and methodologies used in educational practice.

With this premise, in class C, two applications were used, the Periodic Table Quiz and the Periodic Table Educalabs, before applying the questionnaire, as a way to reaffirm the content seen:

The "Periodic Table Educalabs" is an application that works with a 3D interactive periodic table that provides customization of the layout of the elements (standard or extended table) and allows the visualization of the representation of the atom with its energy levels and respective electrons, as well as some characteristics general information on each of the elements, data on periodic properties, data on physical properties, historical information on the elements (such as discovery and isolation of the element) (Nichele \& Schlemmer, 2014).

Figure 1 - Representation of periodic property in the three-dimensional periodic table in the App 'Periodic Table Educalabs'.

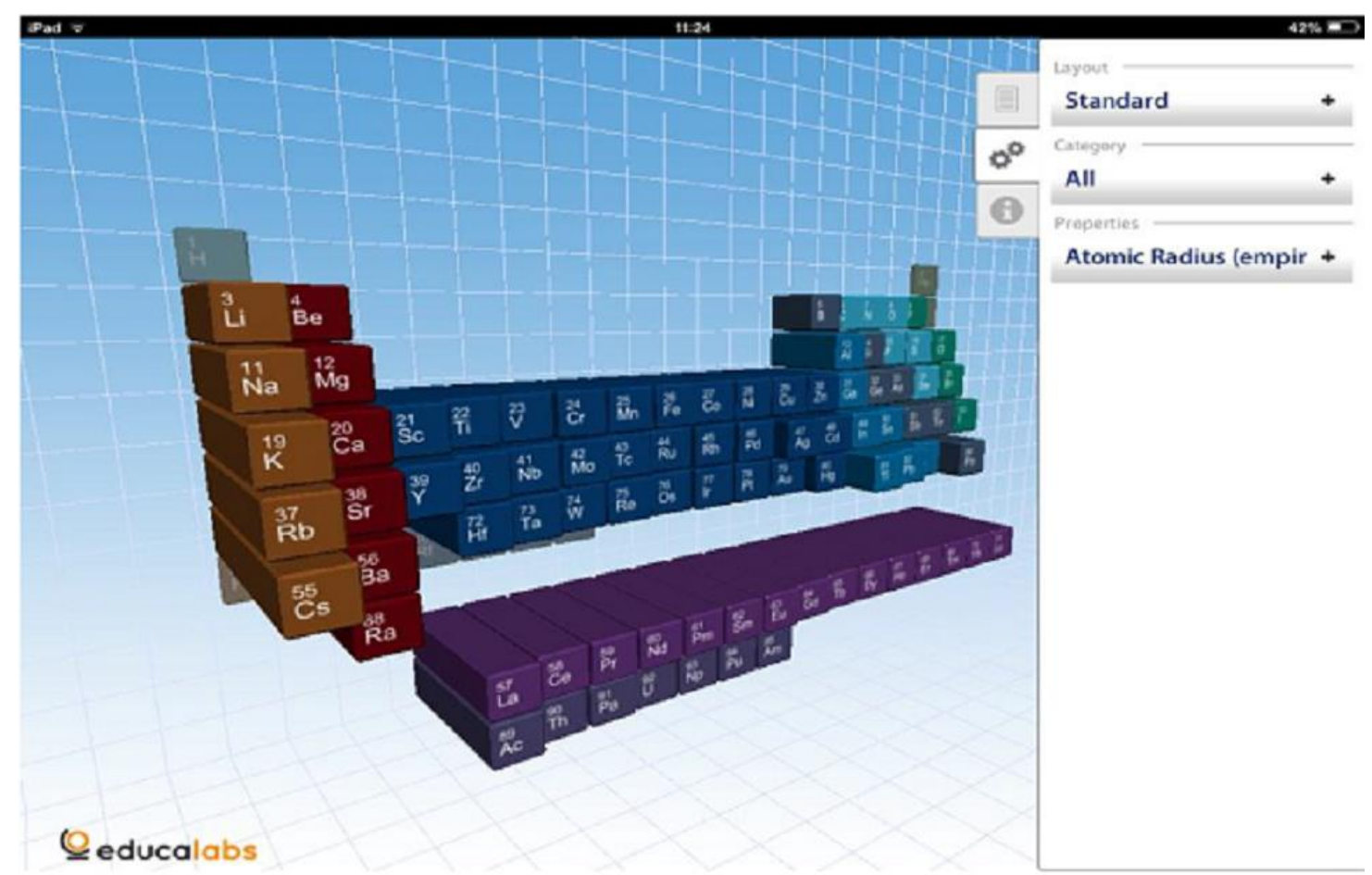

Source: Authors. 
The game Periodic Table Quiz which aims to test knowledge about the most diverse chemical elements, as to the identification, period, groups in which they are located and symbols, so that students become familiar with the periodic table. It contains 29 levels, most of which are blocked, and only the next level is unlocked when the player can reach the score with hits above $50 \%$. The first level is very basic. It shows the chemical element's name with several options of symbols, to choose the correct one, going to another question only when the correct answer occurs, and for each wrong answer, 30 points are lost. It also takes time into account, the lower, the better the score. The other levels work with atomic numbers, groups of elements, periods, and increasing levels increase the difficulty (Silva, 2015).

Figure 2 - Periodic table Quiz application interface.

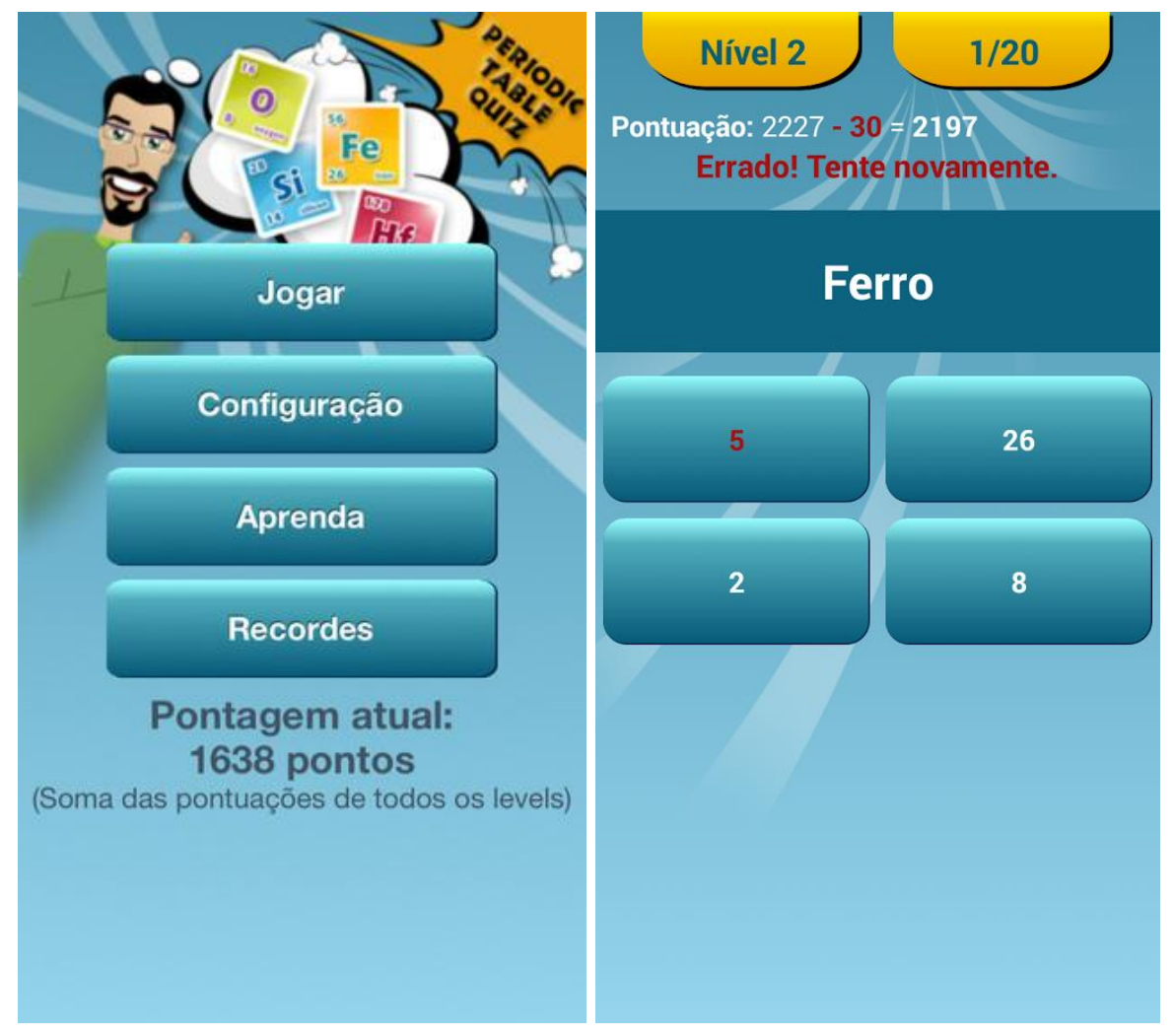

Source: Authors.

According to the data obtained, there was a significant improvement in student performance, as shown in Graph 2 
Graph 2. Comparison between classes, regarding the number of correct answers for the proposed questions.

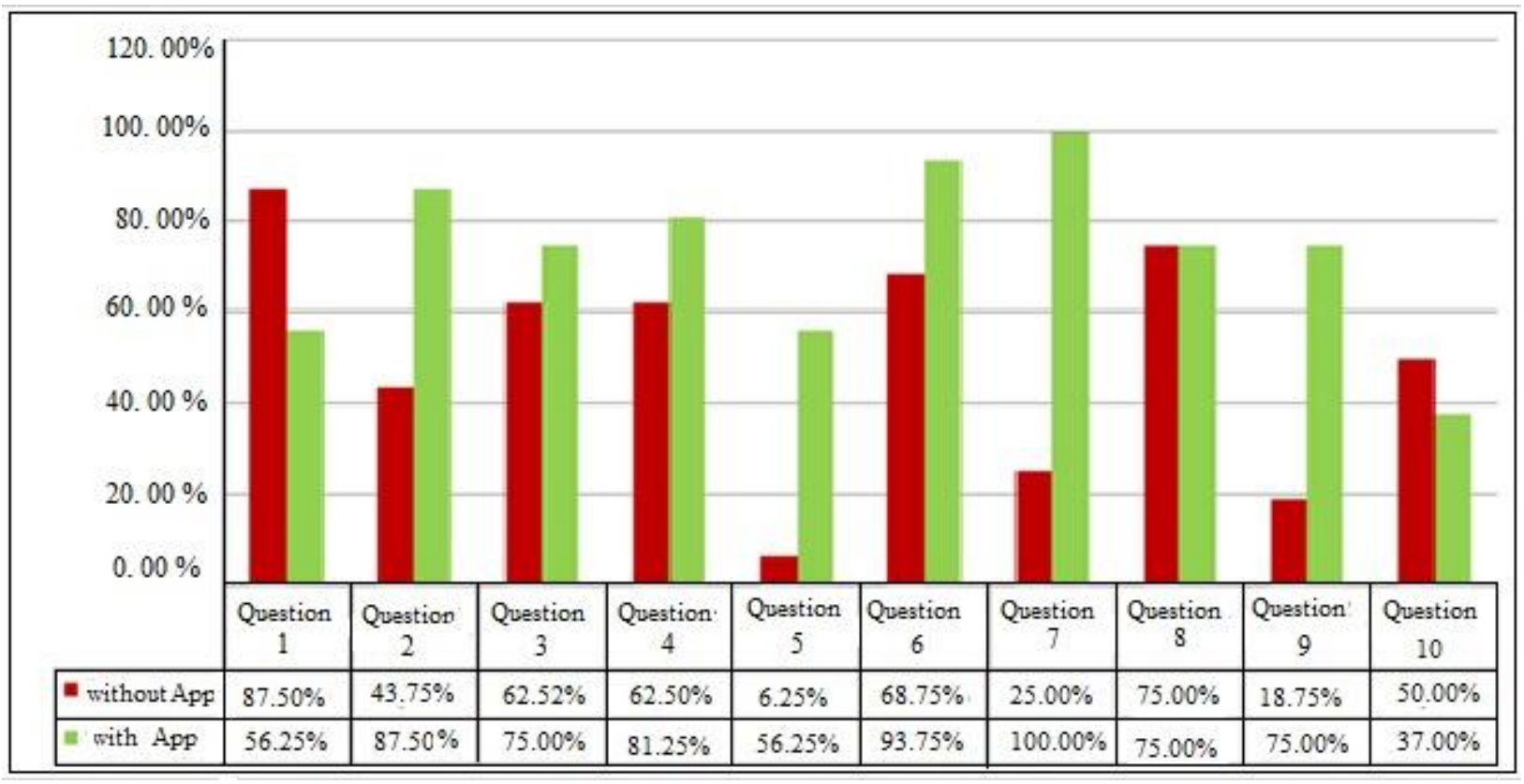

Source: Authors.

After using the applications, it can be seen that there were more hits in 08 of the 10 proposed contributed to this improvement. For example, in question 02, the number of correct answers jumped from $43.75 \%$ to $87.5 \%$, since one of the main subjects dealt with within the game was the atomic number. In question 09, the percentage of correct answers went from $18.75 \%$ to $75 \%$, corroborating that after using the applications, students obtained a better reading of the subject.

In the view of Giordan (2008), in teaching and learning, the use of mobile devices aimed at teaching Chemistry can provide students with learning that correlates a phenomenon from its macroscopic dimension with the submicroscopic and symbolic dimensions.

It is known that technology and education have always had a loving relationship, especially when it comes to the classroom. Although the school model has changed little over time, digital culture is a reality among students and teachers, which has challenged tradition. With the spread of smartphones, schools, governments and other institutions are turning to enhance this technology in improving teaching and learning (Gresczysczyn, 2016).

To analyze the acceptance of using the applications, students answered an evaluative questionnaire. Regarding the use of applications to understand the Periodic Table concepts, 94\% of students answered that their use reinforced knowledge, as shown in Graph 3. 
Graph 3 - The use of applications to understand the concepts of the Periodic Table.
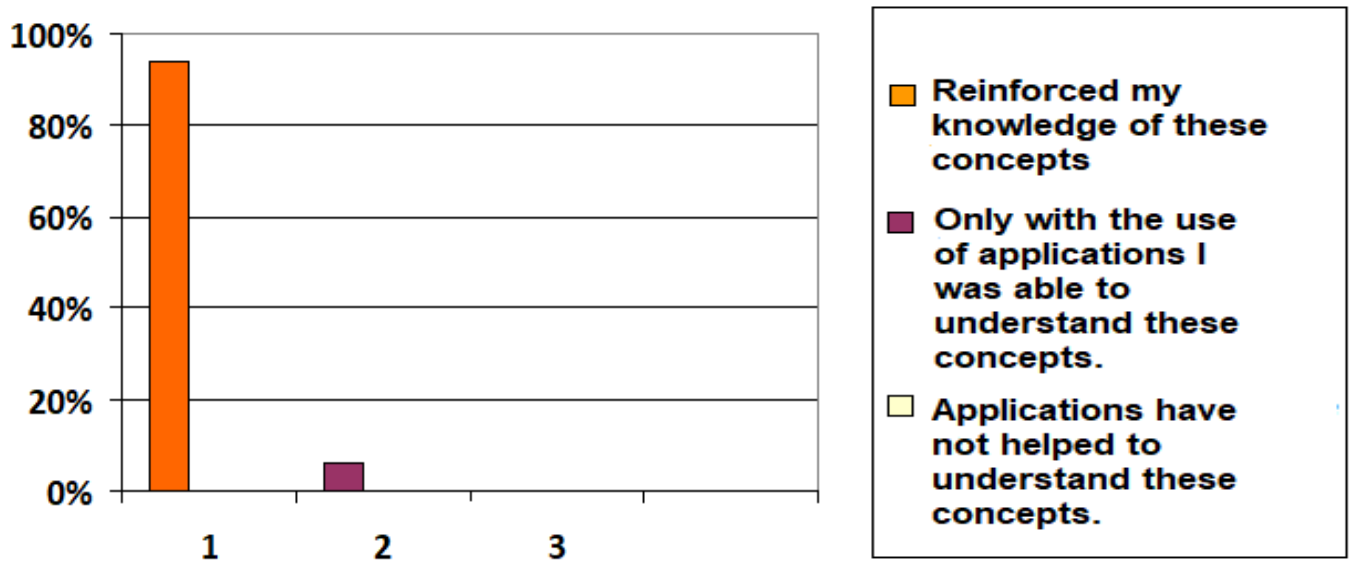

Source: Authors.

The use of teaching resources is a good way to streamline learning as audiovisual resources, which are increasingly used in our schools, enable students and teachers to expand their knowledge, allowing an expansion that is not possible when using only the blackboard (Castoldi \& Polinarski, 2009).

When asked if they would like new Chemistry content to be worked on using applications, 100\% said yes, and that after class with the use of this resource, their interest in the subject's contents increased. In this regard, Diliberto-Macaluso \& Hughes (2016) say that young people are more likely to download and like various applications on their smartphones and tablets, spending more time using these applications on their mobile devices can be effectively integrated with an introductory psychology class to enhance student learning.

Regarding the role of using technological tools in Chemistry Teaching, Lima and Moita (2011, p.136) argues:

The use of technological tools, in the teaching of chemistry, must explain its dynamic character, so that chemical knowledge is expanded, not as a set of isolated, ready and finished knowledge, but as a set of interactive teachings that involve interdisciplinarity, contextualization and technology, enabling the construction of knowledge focused on life.

For Chemistry Education, smartphones, tablets and their Apps can provide experiences and experiences previously restricted to expensive software or a laboratory experiment. Some of these Apps allow, for example, drawing chemical structures on the screen of these devices, visualizing molecules, their three-dimensional structures, a database 
of compounds and chemical elements, among other possibilities (Nichele \& Schlemmer, 2015).

For Gresczysczyn (2016), these applications that can be used can be easily found on systems, such as Google Play, a service provided by Google Inc. The Google Play Store is a Google store for mobile phones with the system Android, in which its users can find all applications for the platform, as well as games, music, movies and books. The store has millions of apps of different genres - among them social networks, messengers, for entertainment, browsers, security and photography software, in addition to selling and renting movies online, offered by third parties, hundreds of thousands of developers send content to Google Play store and millions of users download the content. The service allows the remote installation of apps. That is, from the PC, the user can trigger the installation of an app on the smartphone.

Thus, the new information and communication technologies, characterized as media, are more than simple supports because they interfere in our way of thinking, feeling, acting, socially relating and acquiring knowledge, thus creating a new culture and a new model of society (Kenski, 2004).

The simplicity and practicality to use, the exchange of information, and the facility installing applications on smartphones offer multiple features and contribute to the rapid acceptance and dissemination worldwide. Given these characteristics, the use of these devices in the educational context becomes obvious and natural. However, the educational perspective is provided by installing specific applications, which give smartphones the possibility to develop activities within the scope of teaching and learning processes (gresczysczyn, 2016).

Nichele \& Schlemmer (2014) emphasize that these applications must be used intelligently, especially in the quest to overcome the reproduction of learning models based on the delivery of content, as called by Freire (1987) "bank education". The use of mobile devices and applications in the educational context must be planned to go beyond the reproduction of content in an analogical to digital way, not reaching the expectation of knowledge production and development of student autonomy. It must be adopted together with methodologies problematizing, with open and flexible pedagogical mediation.

In this sense, Gresczysczyn (2016) argues that:

It is necessary to have a critical and problematizing look at the speeches that only aim to incorporate mobile technologies in the school without any discussion about the pedagogical proposal, about learning times and spaces, contributing to a merely passive use of mobile technologies without exploring the full potential that mobile 
devices present for creative appropriation and for teaching and learning beyond classroom spaces.

And it is in this society, where it increasingly brings "demands, experiences and expectations of young people towards a teacher and towards the traditional school" (Gabriel, 2013) that the school should not be restricted, it is necessary to think about how these technologies can contribute to the teaching and what transformations are necessary (Santos, 2017).

Few studies in the literature involve tablets and smartphones and mobile learning for teaching and learning Chemistry (Libman \& Huang, 2013; Ekins et al., 2013; Feldt et al., 2012). Thus, our results presented in this work are considered important, since it highlights this device's potential as a real trend, capable of causing innovation in the teaching and learning processes of Chemistry, through characteristics such as interactivity and mobility.

\section{Final Considerations}

The results of the studies reveal, from the students' point of view, the contribution and potential that the applications offer in the learning of chemical concepts, which suggests that they can be used to enrich the classes, providing great advantages when compared to traditional classes since after use of applications, it can be seen that there were more hits in 08 of the 10 questions proposed and $100 \%$ of them said that the chemistry content should be worked with the use of applications, just as $100 \%$ stated that their interest in the discipline increased.

With that, it is clear that the applications used contributed to the improvement in learning and interest in the discipline, showing that the need to insert new technologies to assist Chemistry classes becomes increasingly important, as it provides students with access to chemical knowledge in conjunction with its social and technological context. However, we understand that only knowing this technology is not enough for innovation in teaching chemistry learning to happen. It is also necessary that the teachers signify their use, that they have an understanding of how the subject learns in the interaction with these applications so that they can develop methodologies capable of causing significant changes in the way of teaching and learning Chemistry. 


\section{References}

Brasil, S. B., \& Santos, B. P., \& Ferenhof, E. A. (2018). Mobile learning: um estudo exploratório sobre aprendizagem com mobilidade no Brasil. IJKEM, INT. J. KNOWL. ENG. MANAGE, 7(19), 12-24. Retrieved from http://incubadora.periodicos.ufsc.br/index.php/IJK EM/article/view/5239.

Bedin, E., \& Carminatti, B. \& Gonçalves, M. K., \& Casoll, C. Metodologia de ensino para Cinética Química: um caminho para a aprendizagem no viés tecnológico-experimental. Divisão de Ensino de Química da Sociedade Brasileira de Química (ED/SBQ) Dpto de Química da Universidade Federal de Santa Catarina (QMC/UFSC). Anais... Santa Catarina. Retrieved from http://www.eneq2016.ufsc.br/anais/resumos/R0009-1.pdf.

Bueno, L., \& Moreira, K. DE C., \& Dantas. D. J., \& Wiezzel. A. C.S., \& Teixeira. M.F.S.O. (2008). Ensino de Química por meio de atividades experimentais: a realidade do ensino nas escolas. In: II Encontro do Núcleo de Ensino de Presidente Prudente. São Paulo: Universidade Estadual Paulista. Anais... São Paulo. Retrieved from https://www.google.com/url?sa=t\&rc $\mathrm{t}=\mathrm{j} \& \mathrm{q}=\&$ esrc $=\mathrm{s} \&$ source $=$ web $\& \mathrm{~cd}=\& \mathrm{cad}=\mathrm{rja} \&$ uact $=8 \& \mathrm{ved}=2 \mathrm{ahUKEwj7joKr} \_$ffrAhUcJrkGH aykA-QQFjAAegQIBhAB\&url=http\%3A\%2F\%2Fwww.unesp.br\%2Fprograd\%2FE NNEP\%2FTrabalhos\%2520em\%2520pdf\%2520-\%2520Encontro\%2520de\%2520Ensi no\%2FT4.pdf\&usg=AOvVaw2-x_xMQ_KnU7CLP_-nY1GM.

Camillo, C. M., \& Medeiros, L, M. (2018). Teorias da educação. Camillo, Cíntia Moralles Teorias da educação [recurso eletrônico] / Cíntia Moralles Camillo, Liziany Müller Medeiros. - Santa Maria, RS : UFSM, NTE. 1 e-book : il. Retrieved from https://www.ufsm.br/app/u ploads/sites/358/2019/06/MD_Teorias_da_Educa\%C3\%A7\%C3\%A3o_Diagrama\%C3\%A7\% C3\%A3oFinal.

Castoldi, R., \& Polinarski, C. A. (2009). A utilização de recursos didáticopedagógicos na motivação da aprendizagem In: Simpósio Nacional de Ensino de Ciência e Tecnologia, 1, Ponta Grossa, 684-692. Anais... Ponta Grossa. Retrieved from https://atividadepara educac aoespecial.com/wp-content/uploads/2014/09/recursos-didatico-pedag\%C3\%B3gicos.pdf. 
Diliberto-Macalus, K., \& Hughes, A. (2016). The Use of Mobile Apps to Enhance Student Learning in Introduction to Psychology. Teaching of Psychology, 43(1), 48-52. https://I: $10.1177 / 0098628315620880$.

Ekins, S., \& Clark, A. M., \& Williams, A. J. (2013). Incorporating green chemistry concepts into mobile chemistry applications and their potential uses. ACS Sustainable Chemistry \& Engineering, 1(1), 8-13. https://doi.org/10.1021/sc3000509.

Feldt, J., \& Mata, R. A., \& Dieterich, J. M. (2012). Atomdroid: A Computational Chemistry Tool for Mobile Platforms. Journal of Chemical Information and Modeling, 52, 1072-1078. https://doi.org/10.1021/ci2004219.

Freire, P. (1987). Pedagogia do Oprimido. (17th ed.), Rio de Janeiro: Paz e Terra.

Gabriel, M. (2013). Educ@r a (r)evolução digital na educação. São Paulo. Editora Saraiva.

Giordan, M. (2008). Computadores e linguagens nas aulas de ciências: uma perspectiva sociocultural para compreender a construção de significados. Ijuí: Editora Unijuí.

Gresczysczyn, M. C. C., \& Filho, S.C.F, \& Monteiro, E. L. (2016). Aplicativos Educacionais para Smartphone e sua Integração Com o Ensino de Química. Revista de Ensino, Educação e Ciências Humanas, 17(5), 398-403. https://doi.org/10.17921/2447-8733.2016v17n5p398-403.

Kenski, V. M. (2004). Tecnologias e ensino presencial e a distância. Campinas: Papirus.

Libman, D., \& Huang, L. (2013). Chemistry on the Go: Review of Chemistry Apps on Smartphones. Journal of Chemical Education, 90, 320-325. https://doi.org/10.1021/ed300329e.

Lima, E. R. P. O., \& Moita, F. M. G. S. C. (2011). A tecnologia e o ensino de química: jogos digitais como interface metodológica. 279. EDUEPB, Campina Grande. 
Nichele, A. G., \& Schlemmer, E. (2014). Aplicativos para o Ensino e Aprendizagem de Química. Novas Tecnologias na Educação, 12, 1-8. https://doi.org/10.22456/16791916.53497.

Nichele, A. G., \& Schlemmer, E. (2015). Percursos de uma prática pedagógica com o uso de tecnologias móveis e sem fio na licenciatura em química. In:37 $7^{\mathrm{a}}$ Reunião Nacional da ANPEd, Anais... Florianópolis-SC. Retrieved from http://37reuniao.anped.org.br/wpcontent/uploads/2015/02/Trabalho-GT16-4309.pdf.

Pinheiro, I. A. D. M., \& Souza, Á. D. M., \& Moreira, E. F., \& Bertini, L. M., \& Fernandes, P. R. N., \& Alves, L. A., \& Lustosa Filho, J. A. (2016). Elementum-lúdico como ferramenta facilitadora do processo de ensino-aprendizagem sobre tabela periódica. HOLOS, 8, 80-86. https://doi.org/10.15628/holos.2015.3647.

Santos, A. P. (2017). O ensino de química na perspectiva do modelo CTS nas escolas centros de excelência da cidade de Aracaju/SE. 165. dissertação (Mestrado em ciências e matemática) Universidade Federal de Sergipe, Sergipe.

Santos, M. C., \& Almeida, L, R; \& Filho, P. F. S. (2020). O Ensino Contextualizado de Interações Intermoleculares a partir da Temática dos Adoçantes. Ciênc. educ., 26, 1-16. https://doi.org/10.1590/1516-731320200028

Silva, P, F., Silva, T., \& Silva, G. N. (2015). StudyLab: Construção e Avaliação de um aplicativo para auxiliar o Ensino de Química por professores da Educação Básica. Revista Tecnologias na Educação, 13, 1-12. Retrieved from http://tecedu.pro.br/wpcontent/uploads/2015/12/Art25-vol13-dez2015.pdf.

UNESCO. Policy Guidelines for Mobile Learning. (2013). Retrieved from http://unesdoc.unesco.org/images/0021/002196/219641E.pdf. 


\title{
Percentage of contribution of each author in the manuscript
}

\author{
Maria Idaiane Bezerra Cavalcante - 14\% \\ Jakson Fernandes Lima - 12\% \\ Railo Cavalcante Nunes $-10 \%$ \\ Daniel Alves da Silva - 10\% \\ Glória Fernandes Lima - 10\% \\ Rubya Macêdo Lima - 10\% \\ Rosilene Rosa Rodrigues - 10\% \\ Maria Izabel Florindo Guedes - 10\% \\ Luiz Francisco Wemmenson Gonçalves Moura - 14\%
}

